\title{
The Achievement of John T. Frederick
}

\author{
S A R E N T B US H, J R. \\ "Nature and Books belong to the eyes that see them." \\ Emerson
}

Excellent teaching is a high art, as those who have tried to achieve it have reason to know. Its essence is elusive and largely beyond the reach of criticism. Its achievement is not reducible to rules, despite the efforts of some to make it into a science, and its success depends as much upon the teacher's personality and character as upon his ability to organize a lecture or class discussion. As Gilbert Highet wrote, "Teaching is not like inducing a chemical reaction: it is much more like painting a picture or making a piece of music, or on a lower level like planting a garden or writing a friendly letter. You must throw your heart into it, you must realize that it cannot all be done by formulas, or you will spoil your work, and your pupils, and yourself." 1 Fortunately, the art is alive and well, though as always, uncommon. Jacques Barzun observed a quarter-century ago that "teaching is not a lost art but the regard for it is a lost tradition. Hence tomorrow's problem will not be to get teachers, but to recognize the good ones and not discourage them before they have done their stint." 2

In the light of Highet's and Barzun's comments, it is especially reassuring to be able to observe in John T. Frederick, who began and ended his teaching in his home state of Iowa, a man who has been throughout a long and distinguished career an authentic practitioner of the fine art of teaching. That Frederick sees the teacher's role in much the same terms as those suggested by Highet is ciear to any who have studied under or worked with him. That he would admit to being such an artist is highly unlikely; indeed, he has publicly warned students who intend to become teachers that "We are never good

1 Gilbert Highet, The Art of Teaching (New York, 1950), p. viii.

2 Jacques Barzun, Teacher in America (Boston, 1945), p. 12. 
enough." 3 But for sixty years he has been the fine artist, determined to "do his stint." In 1911, at the age of eighteen, he began his teaching career as Superintendent and sole high school teacher in Prescott, Iowa. He eventually became Chairman of the English Department at the University of Notre Dame, a post from which he retired in 1962. In less than a year after this ostensible retirement from active teaching, however, he was back in the classroom as Visiting Professor of English at The University of Iowa, a post he held, usually on a parttime basis, for eight years, stimulating his students by his example as well as his instruction to a true desire to learn and to experience the best in literature.

But John T. Frederick has been a good deal more than an excellent teacher; he claims our attention as well for a great variety of other accomplishments which, together, have contributed to a richly significant career of dedication to the arts and letters. In particular, his active concern for the condition of American letters has been expressed in his practice as critic, fiction-writer, poet, editor, and scholar as well as in his teaching. His achievements thus refuse to submit to a single category but have all contributed to the full understanding of literature which he brought to the classroom. He has been, for sixty years, a practicing humanist. I propose, therefore, to attempt to draw together the major strands of the public life and career of John $T$. Frederick in order to suggest the fullness of his accomplishment and the extent to which it has been and continues to be a personal, unique, and worthy one.

It is particularly satisfying, given the truth of Barzun's comments about the rarity of our recognition of excellence in teaching, to notice that when Frederick retired from full-time college teaching and from his position as Chairman of the Department of English at the University of Notre Dame in June, 1962, his numerous contributions to that institution and the world of letters generally were acknowledged in the highest tangible manner available to the Academy, the awarding of its honorary degree. ${ }^{4}$ The award recognized more than his teaching, of course, and any list of his significant accomplishments must include his founding and editing of a major regional literary magazine, The Midland, his teaching what may have been the first college course in contemporary American literature, ${ }^{5}$ and his publica-

3 In "Lines Addressed to a Large Class," The CEA Critic, XXIX (April 1967), p. 8.

4 The degree conferred was the Doctor of Letters.

5 Frederick's own comment on this possibility was: "In 1922 I began to teach at the State University of Iowa what was, I believe, the first course in contemporary American literature ever offered at an American university. I have been 
tion of three novels, a book on the craft of short story writing, several edited collections of literature, numerous scholarly articles, a major book on nineteenth-century American novelists, and a forthcoming book on the English author-naturalist W. H. Hudson. It is an indication of his full intention to "do his stint" as a scholar as well as a teacher that since his "retirement" in 1962, while teaching hundreds of students at The University of Iowa, he has published some eleven articles in scholarly journals, two high school text books, numerous book reviews in various publications from The Rotarian to American Literature, and even a poem in the highly respected Poetry. Since one of his reasons for stepping down from his teaching position at Iowa was that he wanted more time to complete several writing projects, there is no indication that, at seventy-seven, he is inclined to rest from his labors in the cause of good literature.

If anything is clear in reviewing the career of John T. Frederick, it is the great importance to all that he has done of his rural midwestern origins. He recognized this himself when, in an article published in 1951, he observed, "I was born and grew up on an Iowa farm-a rather poor farm, duly equipped with a mortgage. And although I no longer live in Iowa, there has been no year in the more than fifty since I was old enough to ride the horse hoisting hay in which I have not done a considerable amount of common farm work with my own hands." 6 More than once during his career he left teaching altogether in order to help full time on the family farm. At such times, when he returned to his adopted Alcona County in the northern part of the lower peninsula of Michigan, he took an active interest in public affairs there. $\mathrm{He}$ accepted appointment as a member of the Alcona County Road Commission, and was later elected president of the Michigan State Association of Road Commissioners. He also helped to bring about in Alcona County the consolidation of a dozen small school districts into one county district, which led eventually to the erection of a large modern high school building on a beautiful wooded site first suggested by Frederick, and of four new and modern elementary schools in various communities of the district. On retiring to Iowa City in 1962, he and Mrs. Frederick took up residence a few miles to the east of town on a farm operated by members of the family, where they still spend most of the year, the rest typically being spent at "Glennie," a large farm in Alcona County which Frederick as a young man helped to clear and break to the plow.

teaching such courses ever since." In "The Farm in Iowa Fiction," The Palimpsest, XXXII (March 1951), p. 150.

6 Ibid., p. 123. 
The combination of farming with the intellectual life is one which few people have been able to manage successfully. One thinks of $\mathrm{Na}$ thaniel Hawthorne's rejection of his experiment in communal and agricultural living at Brook Farm, on the grounds that shoveling manure in the mornings crippled the aesthetic impulses he hoped to indulge in the afternoons. John Frederick has undoubtedly thought often of this reaction by Hawthorne. But that he has seen the problem somewhat differently is indicated not only by his continued contact with the farm but also by the central conflict in two of his three novels written during the 1920s. ${ }^{7}$ Both Druida and Green Bush dramatize the internal conflict of a person capable of a life of intellectual pursuits who is forced to choose between this and life on a farm. Both Druida and Frank, the protagonists of the novels, opt for life on the farm. Despite the physical and financial hardships that they know will accompany their decisions, they feel that the subjective value to the soul of continued close contact with woods, hills, fields, and the natural cycle of birth and death is of high enough value to outweigh other considerations. "It isn't what a man does that counts-to him," " says Frank in Green Bush. "It's what he thinks and feels that make his life." 8

What John Frederick has thought and felt throughout his career has had much to do with his continued contact with his midwestern farm background. This background has been expressed most significantly in his impulse to establish and to edit for some eighteen years The Midland: A Magazine of the Middle West, a "little magazine" of consistently high quality dedicated to the aim of providing a forum for midwestern literary voices. His editorials in The Midland offer frequent evidence of his own continuing closeness to the land and nature. His expression of the subjective value of the beauties of nature ranges in these editorials from a personal description of and response to the details of his surroundings to clear-headed sociological observation on the dangers in the increasing urbanization of America. He wrote in the

7 In addition to copies of these and other of Frederick's published works The University of Iowa Library contains, as a part of its Iowa Authors Collection, numerous manuscript letters and newspaper clippings, copies of the first, second, and fourth printings of Druida (New York: Alfred A. Knopf, Inc., 1923) as well as copy number 33 of a pre-publication limited edition of the novel inscribed by Knopf to Frederick, the original longhand manuscript, an incomplete intermediate typed manuscript, the press copy typed by Ruth Suckow, and revised galley proofs with corrections. Material related to his second novel, Green Bush (New York: Alfred A. Knopf, Inc., 1925), includes the first (and only) edition and a carbon copy of the press copy of the manuscript. Finally, the library holds a nearly complete file of the issues of Wallaces' Farmer in which his third novel, Stockade, appeared serially between December 2, 1927 and May 4, 1928 and a carbon copy of the final typescript. All of these items were the gift of the author.

8 Green Bush, p. 296. 
former vein from his farm in Michigan on September 15, 1922, for instance, when he closed his editorial comments with the following paragraph:

I am writing these editorials . . . at Glennie. The season is one of supreme beauty in a region always beautiful. The sweep of the long reaches of second growth is suffused with a richness of the approach of autumn. Half hidden by the roadside and about the lake blaze single limbs of maple already colored: ripe orange, vivid scarlet, crimson. The lakes sleep, their waters dulled to gray by the gardens of strange plants that rim their depths. The last whippoorwills call, the bluebirds and plovers gather for their flight. The time and place have, even in this brief sojourn, something of such fulfillment as life accords us. Here is, for today, "Perfected beauty, wholly of the earth."9

The preceding year he had written of long wagon rides over midwestern countryside taken at different points in his lifetime. He detailed three such experiences in particular, the last revealing especially well his awareness of the ultimate and deep importance of one's exposure to nature:

The third drive, of some thirty miles on a bright October day, was shared by the editor's wife and little son. The last quarter of the way was after sundown, through interminable avenues of pines, with stars for light on the dim gray trail. An old mowing machine banged and chuckled behind the wagon, which was piled with miscellaneous prizes from that most interesting of market-places, a country auction. While the horses rested, an hour from home, food and the sweet air refreshed us.

Strangely, or perhaps not strangely, fortitude comes from the silence. Happiness grows like a strong plant in the presence of the beauty of the wilderness. The day's adventuring yields goods not to be hauled in wagons. ${ }^{10}$

Such deeply felt Thoreauvian reflections as these in so unlikely a place as the editorials of a literary magazine suggest that Frederick is himself a naturalist at heart. His vocal admiration-particularly well remembered by his students because of its obvious deep significance for him-for such writers as Joseph Wood Krutch and W. H. Hudson is, in this context, no surprise whatever. Nor is his occasionally more hard-headed approach to America's loss of its contact with nature. He was more than forty years ahead of the current popular concern for ecology when he wrote the following comments in The Midland:

Increasingly numerous and influential in American letters are those writers and critics who are urban to the core of their experience. The

9 The Midland, VIII (September 1922), p. 296.

10 The Midland, VII (June 1921), pp. 247-248. 
older American writer, like Americans of an earlier generation generally, was typically a man or woman familiar with farm and village life, acquainted with occupations and emotions intimately related to the earth. His study window opened on the fields. Sky, soil, and sun were real to him.

But to the new generation of urban Americans, and to the writers among these especially, the apartment, the subway, the pavement are the realities. Fields, forests, streams, are remote, figurative, not felt or understood. To a person whose whole life has been definitely urban, in the modern sense, many of the prevailing ideas of earlier literature are incomprehensible and absurd, and its very language is obsolete. What can such expressions as "to dig deep," "to go to the root of things," "to plough a straight furrow," mean to a man who has never handled a spade, or set out a tree, or seen a plough?

One cannot say that it is right or wrong that this should be. Whether or not the race can survive if the centripetal force of industry keeps crowding the population into cities is a biological question, and no one knows the answer. My own opinion-that it cannot-is based upon so great an ignorance that it is valueless, yet not much greater than that of anyone else. It may be that the cities will endure, that they will absorb all, that food will be made in factories and agriculture will disappear, that earth will become a wilderness save for the urban centers of industry. In this field, theory is meaningless. 11

It is significant that this passage turns to the implications for literature of the population-shift to the cities, ending with the observation that "sound fiction can proceed only from sustained and intimate experience." Frederick never says that the only good literature is rural, but he does lament the fact that as America's experience edges away from the farm and the out-of-doors, the chance for effective writing on these subjects becomes increasingly small. He remained true to this principle in his own fiction by writing about the farm from his own experience of it. The result, particularly in Green Bush (the best of his novels in my view) is a novel of convincing and realistic detail, both about the activities of farming and the natural environment. The critical judgment of Roy Meyer, published in a recent study, suggests Frederick's success in basing his fiction on his own "intimate experience": "The case Frederick makes out for the superiority of farm to city life is the strongest early presentation of this position and perhaps the strongest case that has been or can be made for it."12 Meyer quotes a review from The American Farmer which said of this novel: "So far as interpretation of the deepest aspect of farm

11 The Midland, XIV (May-June 1928), pp. 152-153.

12 Roy Meyer, The Middle Western Farm Novel in the Twentieth Century (Lincoln, 1965), p. 85. 
life is concerned, John T. Frederick's 'Green Bush' reaches the high point in recent fiction. Here, as in no other American novel, implicit unity with the soil is given adequate and coherent expression."13

Frederick's early familiarity was not just with the soil, of course, but with a region. Certainly this is relevant to his earliest and most important editorial venture, the founding and editing of The Midland: A Magazine of the Middle West. This bold step, taken with the help and encouragement of others at The University of Iowa in the year of Frederick's graduation from the university, was a venture which was to be of lasting significance to him and to midwestern literature. This was 1915, a year in which twelve literary magazines were launched in America. ${ }^{14}$ The Midland outlived the other eleven, thanks to Frederick's thoroughgoing dedication to his aim of producing a significant and high-quality magazine. Frank Luther Mott, who for some five years was co-editor of The Midland and whose major work was later to be the important A History of American Magazines, put the responsibility for The Midland where it belonged when he wrote that "though he had associates from time to time who shared the burdens of editing and publishing, during the eighteen years of its existence, John T. Frederick was The Midland."15 At the outset of its sixth year of publication, Frederick editorialized on the reason for the magazine's inception and its continued existence:

When The Midland was founded, there was not, as there is not now, any other general literary magazine published between the Alleghenies and the Rockies. The founders were of this region and believed in its worth for humanity. In its life they saw elements of wholesomeness and charm. The people of the region are readers. Some of them have written well; but these have had to seek publication away from their home. A result has seemed to be a tendency to false emphasis, distortion, in literary interpretations. . . . The publisher and the editors of The Midland hope that their familiarity with the life of their neighbors may be helpful to good writers whose interpretations are true. To this degree The Midland was and is sectional. Probably it is not more sec-

13 Ibid., p. 86.

14 Frank Luther Mott, Time Enough: Essays in Autobiography (Chapel Hill, $1962)$, p. 124.

15 Frank Luther Mott, A History of American Magazines (Cambridge, 1968), V, p. 180. Part of the success of The Midland is certainly owing to Frederick's sincere interest in helping those who submitted material, whether or not the work was accepted. Mott commented elsewhere that "John wrote hundreds of letters and notes to would-be contributors, scribbling them by hand; he was always understanding, sympathetic, and constructive in his suggestions. He could remove the sting from a rejection by a kind of epistolary surgery and make a young writer 
tional than other magazines; probably its isolation makes it more conscious of its sectionalism. ${ }^{16}$

Undoubtedly having this purpose in mind, H. L. Mencken once wrote to Frederick to say that The Midland was "probably the most important literary magazine ever published in America." Frederick promptly requested and received Mencken's permission to quote him, which he did for years in publicity for the magazine. ${ }^{17}$ It is equally important to notice, however, that the editor never lost his sense of proportion about the enterprise. In one of his lighter though entirely honest editorials, he wrote:

I hope that The Midland is not thought to take itself too seriously. ... I can say truthfully that of many amusing objects in the world, I have yet to find one so laughable as myself; and my sense of the ridiculous in my doings and person extends to my activities in connection with The Midland. I have no illusions as to the magazine's efficacy or importance. It is evident to me that of the things to be done in our time, The Midland will accomplish very few indeed. I am not under the impression that it is leading the forces of sweetness and light to an overwhelming victory. The Midland will leave the public taste about as it found it, the American literary situation about as it was.

Indeed, I know that no agency, least of all my own imperfect effort, will greatly change the incredible inertia of the thought and conduct of the race. Nor do I mean or want or hope to change it. The Midland, conceived as an enterprise, is foredoomed to failure. But I have not learned that, in a good cause, the certainty of defeat is sufficient reason for refusing the fight. ${ }^{18}$

The truth about The Midland seems to lie somewhere between the views of editor Frederick and enthusiast Mencken. A survey of the magazine's contents reveals that, while it was never the place where major midwestern authors published their material-such authors as Willa Cather, Sherwood Anderson, Sinclair Lewis, Carl Sandburg, and Ernest Hemingway had no need for such an outlet-it was still an important forum for writers of promise who were less well established and who lacked influential contacts in the publishing world. Ruth Suckow, for instance, published her first story, "Uprooted," in the number for February, 1921, which, thanks to Frederick's immediate enthusiasm for her talent and for her use of authentic midwestern

thank him for sending a manuscript back." Time Enough: Essays in Autobiography, p. 127.

16 The Midland, VI (January 1920), pp. 1-2.

17 Mott, A History of American Magazines, V, p. 190.

18 The Midland, VIII (September 1922), pp. 295-296. 
materials, was followed by three more of her earliest stories in the next year and a half. A decade later, a story called "Mary O'Reilley" by "a young Chicago writer" named James T. Farrell appeared, as did early poems by Paul Engle and Mark Van Doren. Numerous other writers whose names are now familiar to the general public as well as to the academic community also appeared in The Midland, though the genres in which they were then working were not always the ones we have come to identify them with. Maxwell Anderson and MacKinlay Kantor, for instance, both placed poems in Frederick's magazine, as did Howard Mumford Jones, Louis Kronenberger, and Cleanth Brooks, who have each gone on to considerable reputations as scholars and critics. Marquis Childs, the now widely-read newspaper columnist, published three short stories in the magazine in the late twenties and early thirties. In addition to these writers, there were of course many whose reputations have never become more than regional but who were, and in some cases still are, capable in individual works of accomplished art-writers such as Phil Stong, August Derleth, Albert Halper, Edwin Ford Piper, Raymond Weeks, and James Hearst.

Edward J. O'Brien, who, beginning in 1915, made it his business every year to comb the literary magazines and to publish an annual volume of the year's best short stories, immediately recognized The Midland as an exceptional publication. In 1916, O'Brien wrote that "One new periodical ... claim[s] unique attention this year for ... recent achievement and abundant future promise. A year ago a slender little monthly magazine entitled The Midland was first issued in Iowa City. It attracted very little attention, and in the course of the year published but ten short stories. It has been my pleasure and wonder to find in these ten stories the most vital interpretation in fiction of our national life that many years have been able to show. Since the most brilliant days of the New England men of letters, no such white hope has proclaimed itself with such assurance and modesty." 19 O'Brien selected as many as three of the magazine's stories in a single year for inclusion in his annual volumes of Best Short Stories, ${ }^{20}$ thus assisting The Midland's recognition. He always remained a friend of the magazine and in 1923 he commented that The Midland was "a remarkable little periodical ... which, for seven or eight years, has served in its obscurity to crystallize all that is seeking a voice in the imaginative life of the Middle West. While it cannot be said that it has discovered any exceptionally forceful artist, its editor and pub-

19 Edward J. O'Brien, ed., The Best Short Stories of 1915 and the Yearbook of the American Short Story (Boston, 1916), p. 9.

20 Mott, A History of American Magazines, V, p. 183. 
lisher, John Towner Frederick, has performed an admirable function in tilling the soil out of which art is most likely to spring."21

Not the least of the magazine's functions was that of reviewing current books. Frederick did much of this himself, though for the period from 1925 to 1930, while Frank Luther Mott was co-editor, Mott and Frederick wrote review columns in alternate months, evenly dividing this function. The journal was on the scene at a very opportune time for this purpose, since a great many significant works of literature appeared during its lifetime. A highly selective list of books reviewed by Frederick himself at the time of their appearance, for instance, includes Edgar Lee Masters' Spoon River Anthology, Carl Sandburg's Chicago Poems, Sinclair Lewis's Arrowsmith, Edwin Arlington Robinson's Dionysus in Doubt, Thomas Mann's Death in Venice, Theodore Dreiser's An American Tragedy, Ernest Hemingway's A Farewell to Arms, Erich Maria Remarque's All Quiet on the Western Front, Thomas Wolfe's Look Homeward, Angel, Edmund Wilson's Axel's Castle, and Willa Cather's Obscure Destinies. These reviews are unfailingly honest and personal, revealing both their author's sensitivity to fine literary accomplishment and his willingness to voice a dissenting opinion when he felt it was called for.

By the time that Frederick was forced to say in the final number in 1933 that "the fourth year of the depression proves to be one year too many for The Midland," it had become important as a truly national literary magazine and was no longer merely regional, though it never gave up its midwestern orientation. It had been a major undertaking and had become a major accomplishment and, especially in its encouragement to innumerable young writers, a worthy monument to the eighteen dedicated years which Frederick gave to it. ${ }^{22}$

While editing The Midland, Frederick had been active in other literary fields as well. He had written three novels and had published

21 The Advance of the American Short Story (New York, 1923), pp. 221-222. One's agreement with the latter part of this statement will depend, of course, on his opinion of the art of Ruth Suckow, an artist whom Frederick had already "discovered" by this time.

22 That dedication had been constantly shared. The final page of the final copy of The Midland, that for March-April and May-June, 1933, is occupied by an editorial in which the final paragraph is as follows:

From its beginning The Midland has been in part, directly and indirectly,

the work of Esther Frederick. Since the removal to Chicago she has ac-

cepted an increasing share of editorial responsibility, and the quality of the

latest volumes is in large degree due to her.

Esther Frederick died in 1952. Several years later Mr. Frederick married Lucy G. Paulus, the widow of his first wife's only brother. She gave extensive help in the library research in various parts of the country which resulted in the publication of The Darkened Sky. 
stories and poems in such magazines as Mencken's The Smart Set and Harriet Monroe's Poetry. In addition, A Handbook of Short Story Writing, which grew out of a series of lectures delivered while he was teaching for a year at the University of Pittsburgh, was published by Alfred Knopf in 1924. In the same year, he published a collection called Stories from The Midland. His interest in young writers continued to find expression in the years immediately following the demise of The Midland, as he published in successive years Good Writing: A Book for College Students (1934) and, with Leo L. Ward as co-editor, Reading for Writing: Studies in Substance and Form (1935). Two other collections reflecting similar interests appeared several years later: Present-Day Stories (1941) and Out of the Midwest: A Collection of Present-Day Writing (1944), while in 1949 Charles Scribner's Sons published a college-level anthology jointly edited by Frederick, Mott, and Joe Lee Davis, one of the first such books to appear as the post-war surge of interest in American literature began in the colleges.

After moving The Midland to Chicago in 1930, in the hope of increasing its financial support and circulation, Frederick assumed the rank of Professor at Northwestern University's Medill School of Journalism. He continued to devote considerable time to book reviewing. For the whole brief life of the ill-fated Chicago Sun, Frederick contributed a weekly column to its Sunday magazine of books, sometimes devoting it to one new book, sometimes treating two or more. He also conducted for a number of years a book department in The Rotarian, official magazine of Rotary International. In the late thirties and early forties he conducted an extremely popular weekly book review program on CBS radio called Of Men and Books, which was carried on some fifty stations across the nation. He gave this program the same dedicated attention that had made The Midland successful. A biographical essay on Frederick which appeared in 1941 described the nature of this radio program and some of its effect on its audience:

So popular has this purely cultural broadcast become that when Mr. Frederick offered his listeners a list of 50 books recommended for Christmas 1940, more than 2,000 requests for copies came in. It is said that the radio public sends in about a thousand letters a month in response to the program. ...

Of Men and Books owes its increasing popularity in large part to the fact that Professor Frederick is a remarkably good speaker who talks of books simply and informally, from a warmly sympathetic viewpoint, with both understanding and humor. His manner of quiet sincerity and convincing enthusiasms for what is good in the current output makes listeners want to read the books themselves. ... Often Mr. Frederick 
invites famous "guest" authors to talk informally about their writings with him. Among those who have spoken on the program are Dr. Lin Yutang, Archibald MacLeish, Marquis Childs and Robert Nathan. Another distinguishing feature is that at least half the books discussed never find their way into best-seller lists.

"That doesn't mean they aren't worth reading," Professor Frederick says. "On the contrary, they frequently are of greater literary merit than works that sell by the hundreds of thousands. But they aren't written by popular authors, or as well publicized. The American reading public consequently is quite unaware of their existence. And that's why I review them. I want my listeners to become acquainted with authors of really important books." 23

This awareness that a reviewer-critic's function is to praise the excellent as well as to put down the bad in no uncertain terms is a refrain which Frederick had sounded frequently in his editorial columns in The Midland, aware as he was of reviewers' frequent abdication of this responsibility. ${ }^{24}$

Beginning in 1948, he began to publish scholarly articles with increasing frequency and from then until now his articles-mostly on American authors-have appeared in The English Journal, College English, Publications of the Modern Language Association, Arizona Quarterly, American Literature, The CEA Critic, and elsewhere. The articles as a group strongly resist any attempt to cast them into a general type or category. They include essays in literary history, deeply researched source-studies such as his authoritative article on Cooper's sources of information on Indians, essays involving wide familiarity with very recent fiction, explications of individual works of fiction, and essays on pedagogy and the philosophy of teaching. ${ }^{25}$ One of his frequent concerns has been to point out works or aspects of works which have been largely ignored or undervalued by most scholars and critics. He has argued forcefully for the merits of such little-

23 Maxine Block, ed., Current Biography, 1941 (New York, 1941), pp. 309-310.

24 For example, in Volume XV (November-December 1929), 273-274, he wrote, "It seems that the unhealthy condition [of the book trade] is primarily due simply to the publication of too many bad books: books obviously and unmistakably imitative, ill-written, shallow, and generally worthless. . . . American criticism as a whole is increasingly erratic, irresponsible, and cowardly. It is far too windy and noisy, yet conciliating and weak-minded. It is wordy, effusive, a criticism by superlatives. ... There is an element in the American reading public which deserves something better from criticism. It needs, and will welcome, critics of intelligence and integrity, who will lay about them with gusto and skill, and when occasion justifies, without mercy."

25 For examples of each of these categories, see the checklist of publications which follows this essay. The titles are, in almost all cases, suggestive of the nature of the contents. 
noticed works, for instance, as Melville's Israel Potter and Clarel, Faulkner's Soldier's Pay, and Thomas Hooker's The Poor Doubting Christian, while also contributing astute, personal comments on such widely-studied works as Henry James's The Portrait of a Lady and Stephen Crane's "The Open Boat."

In the very recent past, Frederick's scholarly work has culminated in the completion of two significant books. One of these, the study of W. H. Hudson mentioned earlier, results both from his lifelong interest in the writings of naturalists and of Hudson in particular and from his desire to see full justice done to literary excellence, whether it be in the works of minor or major authors. His other recent book was published in 1969 by the University of Notre Dame Press. This work, The Darkened Sky: Nineteenth-Century American Novelists and Religion, is the result of some twenty years of labor, sometimes intensive, sometimes sporadic, as is necessary in the life of an active teacher. The book contains six chapters, each dealing with the subject of religion in the life and writings of a major American novelist: James Fenimore Cooper, Nathaniel Hawthorne, Herman Melville, Mark Twain, William Dean Howells, and Henry James. Professor Robert Spiller of the University of Pennsylvania, reviewing this book in American Literature, called it "a collection of six warm and scholarly essays." "In each of these studies," said Spiller, "Mr. Frederick gives us the feeling that now, at least in the specific area of Christian faith, we know the facts, freed from dogmatic preconceptions, about the religious life of one of these men." 26 Here, as in all of his writings, his personal response to the works considered is fully visible. There is no hiding behind the wall of professional jargon, there is rarely vague or unsupported praise for a work, and there is never an unwillingness to dissent from a common opinion when he feels previous readers have failed to evaluate the facts correctly. The book is valuable to scholars in the field of American literature and religion and may eventually perform the important function of encouraging longer studies of religion in the lives and works of these particular writers.

That his second retirement from active teaching has not meant a separation from the concerns of the teacher is indicated by the publication last year of a textbook which he prepared for high-school use -a volume called Participation Texts consisting of stories, with a dramatized version of each as well as Frederick's questions and suggestions for the study of both. The nature of this book is original. But the fact of its appearance is perhaps the most significant thing,

26 Robert E. Spiller in American Literature, XLI (January 1970), pp. 618-619. 
indicating as it does its author's continued dedication to what has been his primary activity: teaching. For despite his many accomplishments, it is in his role as teacher that he has been supremely successful. Those who have studied under him know him as a warm, considerate man who can listen with the utmost patience to the groping and often foolish thoughts of his students, knowing that these are often the necessary preludes to one's discovery of himself and of the joy of learning. They know him, too, as a man who has read widely but who is always interested in the new. Frank Luther Mott, who knew him as well as any man, summarized many of his dominant traits:

Fairly tall and spare in figure, with a prominent nose in a lean and irregularly fashioned face, John Frederick was no Adonis; but there was something about him that always commanded respect. I think it was Virginia Woolf who once visited the Iowa campus and later wrote in the Freeman or New Republic a piece about Frederick that described him as "Lincolnian." That rather embarrassed him, and it was not quite right because it placed him in a heroic pose unnatural to him. Nobody on the campus was less pretentious. Kindly and sympathetic, with a ready sense of humor, Frederick maintained always a certain modest reserve of dignity. Many of his students had an admiration for him that stopped just this side of idolatry. 27

It is certainly a mark of the consistent strength of his nature that, though this paragraph was written about Frederick as Mott knew him at Iowa in the 1920s, there is not a detail in it which would not apply equally well to the John Frederick who taught again at Iowa in the 1960s.

Equally as important as his personal characteristics in his success as a teacher has been his thoroughgoing understanding of what he is about. He fully comprehends the function of the teacher of literature. One of his most important essays, "Lines Addressed to a Large Class," confronts this very issue. Written near the end of his active teaching career, it can properly be seen as a summary of much that he has learned about the function of a teacher and in particular about the role of a teacher of literature. After noting the difficulty of conducting an effective learning experience about examples of literature in the artificial environment of a large college course, he goes on to say to the class, "I do believe in what we are trying to do. I believe that the arts are important, and that for most of us literature is most important of them all. I do believe that what can happen here or in any litera-

27 Mott, Time Enough: Essays in Autobiography, p. 126. 
ture class can make a difference, probably small but potentially great, in each of a few or many lives; not in earning power, perhaps, but in living power." 28 How this is done, he says, is not easily defined. His comments on his convictions about the process, however, coming close to a personal professional credo, are fully as valuable as the insights to be gained in many a formal course in educational theory, coming as they do as the result of more than fifty years in the classroom. He writes:

It is the assumption, implicit or even avowed, that factual knowledge is not only sufficient in itself, that it is indeed the actual purpose of literary study, that I deny and oppose with all my heart. Whether in a course in modern fiction or in reading Beowulf, the factual knowledge should be only a means to an end: that end being always a personal experience of literature, the enlargement and enrichment of the student's private world.

Yes, I believe the study of literature can be immensely and crucially rewarding for the student, be he young or old; and I believe that the teaching of literature is a high calling. But I am keenly aware that I don't know how, and I can't hope, to reach its full potential.

I do know some things, though I fall short of achieving their full realization. I know, first, that I must try to share my own experience of a book, the experience of a fresh, thoughtful reading, no matter how many times I have read it before. I must not give you primarily [or] only things other people have said, things I have found in books and articles; nor must I depend on old notes or faulty memory of what the book offers. Second, I must be sincere. I must not offer you a judgment or an impression merely because it is conventional or fashionable, or has high critical authority behind it. Finally, I must be humble, must not try to impose upon you my own judgments or evaluations. After all, ... each of you is a unique human person. When you all confront the same book, a hundred different equations result, each unique because it proceeds from the relation of that book to you as a person: your total experience of books, of the other arts, of life as a whole; your convictions, aspirations, hopes, and fears. I must remember that this and this only-this inescapably singular personal experience-is what really matters.

Some of you will be teachers of literature, and I think some of you will be very good ones. I think you will see this as a high calling, will give it your best effort, and will find reward in trying to achieve, at least to approach, its potentials. To you I give and bequeath the one firm conclusion I have arrived at in more than fifty years of trying to teach literature: "We are never good enough."29

28 John T. Frederick, "Lines Addressed to a Large Class," The CEA Critic, XXIX (April 1967), p. 8.

29 Ibid. 


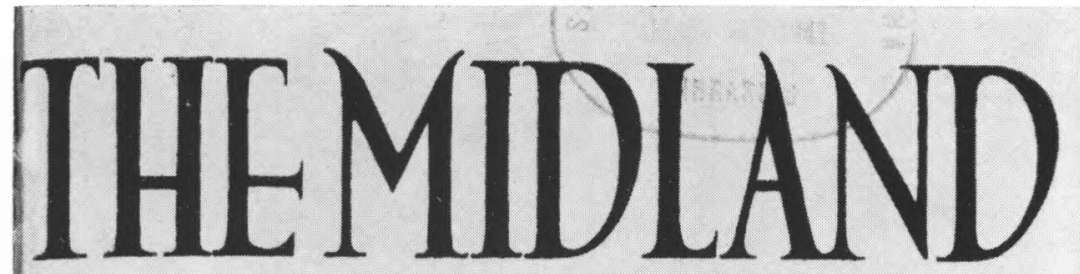

A National Literary Magazine

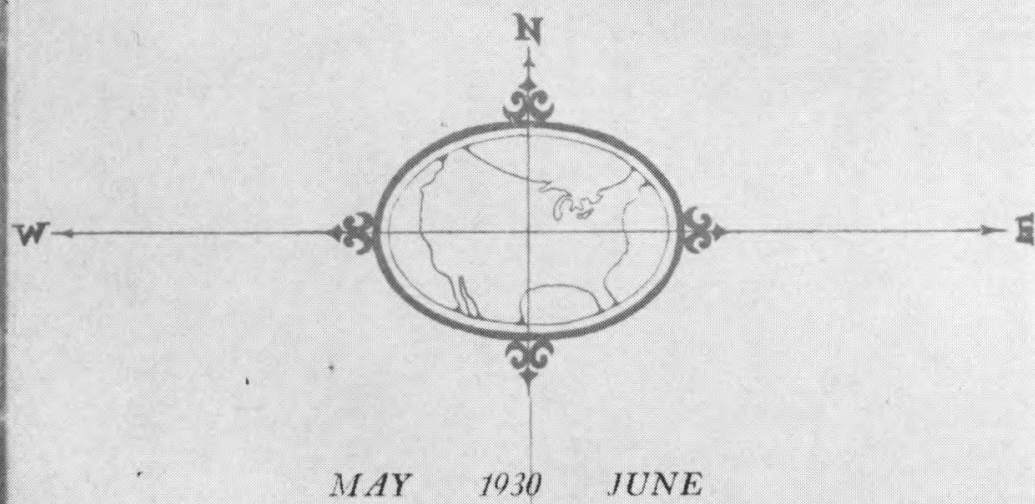

STORIES: Edythe Squier Draper, Paul F. Corey, Mary Katharine Reely.

POEMS: Jay G. Sigmund, Thomas $W$. Duncan, Doren Tharp, Jean Beardslee, Mildred Fowler Field, Loren C. Eiseley, Moe Bragin, Florence Page Jaques,

Nora B. Cunningham, Lee Andrew Weber.

THE SKETCH BOOK: Edith Roles Jacobs, Frances Pearsons Dolliver.

BOOK REVIEWS

BIOGRAPHICAL

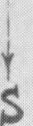

Entered as second class mail matter. Copyright 1930 by John T. Frederick ifty Cents a Copy Iowa City Three Dollars a Year

Front cover of an issue of The Midland, a literary magazine founded and edited by John T. Frederick. 
This is a fitting note on which to end, both because it is so true as a philosophical statement on the art of teaching and because it is so representative of the whole professional stance of John T. Frederick. It explains how he came to establish an important regional magazine before he had even finished his undergraduate education and it explains why, at age seventy-seven, he is still at work exploring the horizons of knowledge and making the discoveries which energize the life of the mind. It explains, too, the presence in his teaching of that indefinable "Quality" which Jacques Barzun has observed to be a mutual component of teaching and art. ${ }^{30}$ It is a privilege and accomplishment reserved for a few to be eminently successful in a "high calling." One of those privileged few is surely John T. Frederick, a man who, more fully than anyone else can describe, knows that the rewards of such success are not tangible gain or even praise but, rather, wealth "not to be hauled in wagons." And, as with all art, the value is hauled away not by master only or student only, but by both.

30 Barzun, Teacher in America, p. 308.

\section{WORKS BY JOHN T. FREDERICK}

\section{5-1919}

THE MIDLAND: A Magazine of the Middle West [Edited and published by John T. Frederick] Vols. I-V, 1915-1919.

"The 'Spoon River Anthology" "[review] The Midland, I, no. 7 (July 1915), 238243.

"Twelfth Night at Fisher's Crossing" [play] The Midland, II, no. 1 (January $1916), 18-24$.

"Carl Sandburg's “Chicago Poems"” [review] The Midland, II, no. 6 (June 1916), 189-193.

"A Legislature that Works," The New Republic, XIV (Feb. 23, 1918), 105-107.

"The Orchard," [poem] Poetry, XV (Oct. 1919), 17.

"Weaving" [poem] Poet Lore, 30 (Dec. 1919), 607.

1920 s

THE MIDLAND: a Magazine of the Middle West [Edited and published by John T. Frederick] Vols. VI-XV, 1920-1929.

“The Legacy" [story] The Smart Set, LXVI, no. 2 (October 1921), 119-126.

"Associate Professor Quinby of the English Department" [story] The Smart Set, LXVII, no. 1 ( January 1922), 108-111.

"The Eternal Pantagruel" [story] The Smart Set, LXVII, no. 3 (March 1922), $40-41$.

"Mirage" [story] The Smart Set, LXVIII, no. 3 (July 1922), 119-130.

"Three Midland Poets" [Mixter, Alexander, Dresbach] The Midland, VIII, no. II (November, 1922), 326-327.

DRUIDA [a novel] With seven woodcuts by Wilfred Jones. New York: Alfred A. Knopf, 1923. (Also 110 copies on Alexandra Japan paper.)

\footnotetext{
*Assistance in compiling this checklist was given by the staff of the Special Collections Department.
} 
“Leyland Huckfield: a Friend's Record" The Midland, IX, no. 12 (December, 1923), 261-266.

A HANDBOOK OF SHORT STORY WRITING. New York: Alfred A. Knopf, 1924.

STORIES FROM THE MIDLAND. Selected and edited by John T. Frederick. New York: Alfred A. Knopf, 1924.

"Barbed Wire and Wayfarers: Edwin Ford Piper" [review] The Midland, X, no. 2 (February, 1924), 100-108.

"Highwaymen, by Charles J. Finger: a Review" The Midland, X, no. 4 (April 1924), 203-205.

"Land O' Maize Folk, by J. G. Sigmund: a Review" The Midland, X, no. 5 (May 1924), 251-255.

"Nelson Antrim Crawford: Poet and Teacher" The Midland, X, no. 11 (November 1924), 417-419.

GREEN BUSH [a novel] With nine drawings by George L. Stout. New York: Alfred A. Knopf, 1925.

"A Note on Charles J. Finger" The Midland, XI, no. 9 (May 1, 1925), 176-177.

"Literary Evening-Iowa Style" in The Borzoi 1925 (New York: Alfred A. Knopf, $1925), 84-87$.

"An American Tragedy: a Review" The Midland, XII, no. 10 (October, 1926), 281-285.

THE STOCKADE: a Story of the Copperhead Plot in 1864 [a novel] Published serially in Wallaces' Farmer, December 2, 1927-May 4, 1928.

"Wild Honey" [story] St. Nicholas, 55 (September, 1928), 897-900.

"I've Been Reading-" [reviews] The Midland, XIV, no. 1, no. 3, no. 5, no. 6; $\mathrm{XV}$, no. 1, no. 4, no. 6 (January-February, 1928 through November-December, 1929).

\section{0s}

THE MIDLAND: a National Literary Magazine [Edited and published by John T. Frederick] Vols. XVI-XX, 1930-1933.

“The Writer's Iowa," The Palimpsest, XI (February 1930), 57-60.

“The Younger School," The Palimpsest, XI (February 1930), 78-86.

"Alumni Foreword," Hawk Wings: The Iowa Literary Magazine (March 1930), 66.

"I've Been Reading-" [reviews] The Midland, XVI, no. 2, no. 4, no. 6; XVII, no. 2 ; XVIII, no. 2 , no. 4 , no. 5 , no. 7 ; XIX, no. 2 , no. 5 ; XX, no. 1 , no. $2-3$ (March-April 1930 through May-June 1933).

"Samuel H. M. Byers and His Contribution to Civil War Literature" in A Book of Iowa Authors by Iowa Authors, edited by Johnson Brigham (Des Moines: Iowa State Teachers Association, 1930), 45-53.

"Five Interpreters of Iowa" [on J. G. Sigmund, W. J. Muilenburg, R. L. Sergel, W. L. Myers, and N. A. Crawford] in A Book of lowa Authors by lowa Authors, edited by Johnson Brigham (Des Moines: Iowa State Teachers Association, 1930), 227-234.

"Ruth Suckow and the Middle Western Literary Movement," The English Journal, XX (January 1931), 1-8.

A HANDBOOK OF SHORT STORY WRITING. Revised edition. New York: F. S. Crofts \& Co., 1932.

"The Place of Creative Writing in Graduate Work in English," Education, 53 (November 1932), 161-163.

GOOD WRITING: a Book for College Students by John T. Frederick and Leo L. Ward. New York: F. S. Crofts \& Co., 1934.

READING FOR WRITING: Studies in Substance and Form [edited by] John T. Frederick and Leo L. Ward. New York: F. S. Crofts \& Co., 1935.

"New Techniques in the Novel," The English Journal, XXIV (May 1935), 355363. 
"A Maker of Songs" [Edwin Ford Piper] American Prefaces, II, no. 6 (March 1937), 83-84.

"J. B. Priestley: All-round Man of Letters on the Eighteenth-Century Plan," The English Journal, XXVII (May 1938), 371-380.

\section{$1940 \mathrm{~s}$}

PRESENT-DAY STORIES. Selected by John T. Frederick. New York: Charles Scribner's Sons, 1941.

READING FOR WRITING: Studies in Substance and Form [edited by] John T. Frederick and Leo L. Ward. New York: F. S. Crofts \& Co., 1941. (First published in 1935. This second edition was published in 1941 and a third edition appeared in 1946.).

"A. J. Cronin," College English, III (November 1941), 121-129.

"Culture of Communities" in Community Life in a Democracy, edited by F. C. Bingham (Chicago: National Council of Parents and Teachers, 1942), 175-186.

"I've Been Reading-" [reviews] The Chicago Sun Book Week, I, no. 1 (November 1,1942 ) through V, no. 49 (September 28, 1947).

OUT OF THE MIDWEST: a Collection of Present-Day Writing, edited by John T. Frederick. New York: Whittlesey House, McGraw-Hill Book Co., Inc., 1944. "Speaking of Books" [reviews] The Rotarian, Vol. 64-Vol. 75 (January 1944December 1949).

“The Quarter Books," College English, IX (May 1948), 407-413.

AMERICAN LITERATURE: An Anthology and Critical Survey. Edited by Joe Lee Davis, John T. Frederick, and Frank Luther Mott. 2 Vols. New York: Charles Scribner's Sons, 1949.

$$
1950 \mathrm{~s}
$$

"Speaking of Books" [reviews] The Rotarian, Vol. 76-Vol. 95 (January 1950. December 1959).

"The Farm in Iowa Fiction," The Palimpsest, XXXII (March 1951), 121-152.

"Town and City in Iowa Fiction," The Palimpsest, XXXV (February 1954), 4996.

"Costain and Company: The Historical Novel Today," The English Journal, LXIII (April 1954), 169-174.

"Worthy Westerns," The English Journal, XLII (September 1954), 281-286.

"Early Iowa in Fiction," The Palimpsest, XXXVI (October 1955), 389-420.

"Fiction of the Second World War," College English, XVII (January 1956), 197 204.

"Iowa in Biography," The Palimpsest, XXXVII (October 1956), 481-512.

"Cooper's Eloquent Indians," Publications of the Modern Language Association, LXXI (December 1956), 1004-1017.

"Iowa's Phil Stong," The Palimpsest, XXXVIII (December 1957), 520-524.

"Love by Adverse Possession: The Case of Mr. Cozzens," College English, XIX (April 1958), 313-316.

"American Literary Nationalism: the Process of Definition, 1825-1850," Review of Politics, XXI ( January 1959), 224-238.

"The Meaning of Literature in America Today" in What America Stands For, edited by I. Kertész and M. A. Fitzsimons (Notre Dame: University of Notre Dame Press, 1959), 115-129.

\section{$1960 \mathrm{~s}$}

"Speaking of Books" [reviews] The Rotarian, Vol. 96-Vol. 101 (January 1960 through December 1962).

"Symbol and Theme in Melville's Israel Potter," Modern Fiction Studies, VIII (Autumn 1962), 265-275.

"Tales of the Prairies" [reviews] The Rotarian, Vol. 102, no. 4 (April 1963), 48$49,70-71$. 
"Books about Bees, Dolphins, and Furry Creatures" [reviews] The Rotarian, Vol. 103, no. 6 (December 1963), 38-39, 61.

ADVENTURES IN FICTION, edited by John T. Frederick. New York: Harcourt, Brace, \& Co., 1964. (Also an accompanying 31-page teacher's manual.)

"Some Good Yarns for the Young" [reviews] The Rotarian, Vol. 103, no. 6 (December 1964), 38-39.

"Lines Addressed to a Large Class," The CEA Critic, XXIX (April 1967), 2, 8.

"Anticipation and Achievement in Faulkner's Soldiers' Pay," Arizona Quarterly, (Autumn 1967), 243-249.

"Notes on Natural History" [poem] Poetry, 111 (December 1967), 169-170.

"Melville's Early Acquaintance with Bayle," American Literature, XXXIX (January 1968 ), 545-547.

"Literary Art in Thomas Hooker's The Poor Doubting Christian," American Literature, XL (March 1968), 1-8.

"Literary Art in Thomas Shepard's The Parable of the Ten Virgins," SeventeenthCentury News, XXVI (Spring 1968), no. 1, item 7.

"The Fifth Man in 'The Open Boat," The CEA Critic, XXX (May 1968), 1, 12 14.

"Hawthorne and the Workhouse Baby," Arizona Quarterly, XXIV (Summer 1968), 169-173.

"Wallace Stevens: A Classroom Approach," The CEA Critic, XXXI (November $1968), 6-7$.

"Patterns of Imagery in Chapter XLII of Henry James's The Portrait of a Lady," Arizona Quarterly, XXV (Summer 1969), 150-156.

THE DARKENED SKY: Nineteenth-Century American Novelists and Religion. Notre Dame: University of Notre Dame Press, 1969.

\section{0 s}

“Melville's Last Long Novel: Clarel," Arizona Quarterly, XXVI (Summer 1970), 151-157.

PARTICIPATION TEXTS, edited by John T. Frederick. Chicago: Dramatic Publishing Co., 1970.

W. H. HUDSON. New York: Twayne Publishers, Inc. (forthcoming).

"Last Lines: Addressed to a Graduate Class," The CEA Critic. Scheduled for publication in May 1971. 